\title{
PENGARUH KETERAMPILAN MANAJERIAL DAN KEPEMIMPINAN KEPALA SEKOLAH SEKOLAH TERHADAP KEPUASAN KERJA GURU SMP SWASTA SE-KOTA PEKANBARU
}

(The Effect of Principals' Managerial Skill and Leadership toward Job Satisfaction on Private SMP Teachers in Pekanbaru)

\section{Oleh: Henderina ${ }^{*)}$ \& Ernamaiyanti ${ }^{* *)}$}

*) Dosen STIE Pelita Indonesia, Pekanbaru

**) Tim Ahli di TPRP S\&P (Urban Research \& Policy) dan Tim Ahli PT. Daya Cipta Dianrancana

\begin{abstract}
The principal is required to have inner skills. That ability will determine whether or not education succeeds on going learning at school. In addition, the principal should also pay attention to the work satisfaction of teachers in the work environment. The purpose of this research is to know 1) to know the influence of managerial skill to job satisfaction of Private Junior High School teachers in Pekanbaru City, 2) to know the influence of leadership capability of headmaster to job satisfaction of junior high school teacher of Pekanbaru City, 3) to know the effect of managerial training and leadership of the principal together towards the job satisfaction of Private Junior High School teachers in Pekanbaru City. This research is a quantitative research with the determination of respondents apply Solvin formula as many as 93 respondents with subject of Private Junior High School as Pekanbaru City. Data type is primary data and secondary data. Data processing methods with editing, coding, scoring process. Data were analyzed by multiple linear regression. The findings of this study include 1) positive managerial skills to teacher work satisfaction of 0.232 or equivalent to $23.2 \%$; 2) leadership ability of headmaster positively influence to job satisfaction of teacher equal to 0,342 or equal to $34,2 \%$; 3) managerial and leadership skills of principals together have a significant positive effect on the dependent variable of job satisfaction of teachers in private Junior High School Pekanbaru.
\end{abstract}

Keywords: Managerial list, principal leadership, job satisfaction

\section{PENDAHULUAN}

Kepemimpinan kepala
mekolah
menentukan galah satu faktor yang
mewujudkan visi menjadi aksi, sehingga
tujuan dan sasaran sekolah dapat tercapai
melalui perencanaan berbagai program yang
telah direncanakan sebelumnya Sistem
pengelolaan (manajemen) sekolah yang
efektif dan efisien bertendensi kepada
peningkatan kualitas pendidikan, demikian
juga sebaliknya. Salah satu peranan dan
tanggung jawab kepala sekolah adalah
sebagai manajer pendidikan. Seorang

pemimpin pendidikan dituntut memiliki keterampilan manajerial yang sesuai dengan situasi dan kondisi yang ada pada lingkup lembaga pendidikan untuk mencapai tujuan pendidikan sekolah, yaitu ketuntasan belajar para anak didik. Selain itu, kepala sekolah juga bertanggungjawab tentang kepuasan guru dan karyawannya.

Kepuasan kerja adalah suatu perasaan positif tentang pekerjaan seseorang sebagai hasil dari sebuah evaluasi karakter-karakter dari pekerjaan tersebut (Robbins dan Judge 
2008). Kepuasan kerja berhubungan erat dengan nilai yang melekat pada seseorang atas pekerjaannya. Pekerjaan seseorang bukanlah sekedar rutinitas tetapi merupakan yang mempunyai nilai yang akan menimbulkan motivasi bagi seorang untuk lebih produktif. Seorang guru akan merasa puas dalam bekerja apabila aspek-aspek dalam pekerjaan dan dirinya mendukung, dan sebaliknya jika aspek-aspek tersebut tidak mendukung, maka guru akan merasa tidak puas.

Robin (2010) mengatakan beberapa variabel yang berhubungan dengan kepuasan kerja. Faktor-faktor tersebut adalah pekerjaan yang secara mental menantang, ganjaran yang pantas, kondisi pekerjaan yang mendukung dan rekan kerja yang mendukung. Namun kenyataan yang ada di lapangan khususnya pada guru SMP Swasta di Pekanbaru, kondisi tersebut masih jauh dari harapan. Hal ini dapat dilihat masih ada keluhan guru tentang kepala sekolah yang kurang kemampuannya dalam merencanakan, memberi solusi terhadap masalah di sekolah, kurang kemampuan dalam mengawasi, membimbing, sehingga suasana sekolah kurang kondusif. Hasil observasi ini, diperkuat dengan hasil wawancara awal yang dilakukan pada 5 (lima) dari 78 sekolah SMP Swasta di Kota Pekanbaru, beberapa guru mempunyai presepsi bahwa kepemimpinan kepala sekolah kurang optimal, kepala sekolah kurang bisa mengidentifikasi permasalahan yang ada di sekolah dan ada juga beberapa guru mengatakan kurang tegasnya kepala sekolah dalam mengambil keputusan dan menegakan peraturan sekolah.

Tujuan penelitian ini untuk mengetahui 1) untuk mengetahui pengaruh keterampilan manajerial terhadap kepuasan kerja guru SMP Swasta se-Kota Pekanbaru,
2) untuk mengetahui pengaruh kemampuan kepemimpinan kepala sekolah terhadap kepuasan kerja guru SMP Swasta se-Kota Pekanbaru, 3) untuk mengetahui pengaruh keterampilan manajerial dan kepemimpinan kepala sekolah secara bersama-sama terhadap kepuasan kerja guru SMP Swasta Se-Kota Pekanbaru.

\section{Metode Penelitian}

Penelitian ini bertempat di Kota Pekanbaru dan dilakukan dari bulan Oktober 2016 - Maret 2017. Penelitian ini menggunakan pendekatan kuantitatif. Populasi penelitian ini adalah seluruh guru SMP Swasta yaitu 1.367orang dari 78 SMP Swasta yang ada di Kota Pekanbaru (Sumber data: Dinas Pendidikan Kota Pekanbaru. 2016). Menentukan ukuran sampel dengan memakai Model Slovin dalam Wahyuni, $d k k .2011)$ dengan rumus:

Keterangan:

$$
n=\frac{N}{1+N d^{2}}
$$

$\mathrm{n}=$ Besar sampel

$\mathrm{N}=$ Besar populasi

$d=$ Tingkat kepercayaan/ ketetapan yang diinginkan yaitu sebesar $10 \%$

Dari model Slovin di atas diperoleh sampel sebanyak 93 orang. Untuk penentuan lokasi penelitian maka digunakan pendapat Arikunto (2010) yaitu $10 \%$ dari jumlah SMP Swasta yang ada di Kota Pekanbaru sehingga lokasi penelitian ada 8 (delapan) SMP Swasta di Kota Pekanbaru.

Tabel 1. Jumlah Sampel Masing-masing Sekolah

\begin{tabular}{llll}
\hline No & Nama Sekolah & Total Guru & Jumlah Sampel \\
\hline 1. & SMP Assofa & 37 orang & 13 orang \\
\hline 2. & SMP Mett Maitreyah & 15 orang & 5 orang \\
\hline 3. & SMP Muhammadiyah 1 & 32 orang & 12 orang \\
\hline 4. & SMPKalam Kudus & 26 orang & 10 orang \\
\hline 5. & SMPDharmaloka & 36 orang & 11 orang \\
\hline 6. & SMPKartika 1-5 & 25 orang & 9 orang \\
\hline
\end{tabular}




\begin{tabular}{llll}
\hline 7. & SMPPGRI & 28 orang & 11 orang \\
\hline 8. & SMPDharma Yudha & 60 orang & 22 orang \\
\hline Total & 259 orang & 93 orang \\
\hline Sumber: Dokumentasi masing-masing sekolah & \\
Jenis data adalah data primer dan data & seluruh item variabel di atas berada di \\
sekunder. Metode pengolahan data dengan & atas 0.202 yang berarti seluruh \\
pengeditan (editing), pemberian kode & pernyataan dari variabel penelitian ini \\
(coding), proses pemberian skor (scoring). & memenuhi syarat dan valid, sehingga \\
Untuk daftar pertanyaan & data dapat digunakan untuk di analisa \\
kuesioner keterampilan manjerial kepala & selanjutnya.
\end{tabular}

sekolah dan kepemimpinan kepala sekolah yang diberikan kepada responden tersebut diberikan skor sebagai berikut :

- $\quad$ Sangat Baik $(\mathrm{SB})=4$

- $\operatorname{Baik}(\mathrm{B}) \quad=3$

- $\quad$ Kurang Baik $(\mathrm{KB})=2$

- Tidak Baik $(\mathrm{TB})=1$

Untuk daftar pertanyaan kuesioner kepuasan kerja yang diberikan kepada responden tersebut diberikan skor sebagai berikut :

- $\quad$ Sangat Puas (SP) $=4$

- $\operatorname{Puas}(\mathrm{P}) \quad=3$

- Kurang Puas (KP) = 2

- $\quad$ Tidak Puas (TP) $=1$

Uji instrument penelitian dengan uji validitas dan uji reabilitas. Sedangkan metode analisis data adalah regresi linear berganda.

\section{Hasil Penelitian \\ Hasil Uji Validitas}

Uji validitas akan menguji masingmasing variabel yang digunakan dalam penelitian ini, dimana keseluruhan variabel penelitian memuat 43 pernyataan yang harus dijawab oleh responden. Hasil korelasi tersebut dibandingkan dengan $r_{\text {tabel }}$ pada tingkat signifikan 0,05 : apabila Corrected Item- Total Correlation atau $\mathrm{r}_{\text {hitung }}>$ dari $\mathrm{r}_{\text {tabel }}$, maka instrumen tersebut adalah valid dan sebaliknya jika $r_{\text {hitung }}$ negatif dan $r_{\text {hitung }}<$ dari $\mathrm{r}_{\text {tabel }}$ maka instrumen tersebut tidak valid (Sugiyono. 2012).

Hasil uji validitas menunjukan keseluruhan nilai pernyataan variabel (Corrected Item-Total Correlation atau $\mathrm{r}_{\text {hitung-nya) memiliki nilai diatas }} \mathrm{r}_{\text {tabel }}$ atau $r_{\text {hitung }}>r_{\text {tabel. }}$. Hal ini menunjukkan bahwa

\section{Hasil Uji Reabilitas}

Pengujian reliabilitas bertujuan untuk memenuhi konsistensi hasil pengukuran variabel. Pengukuran yang reliabel akan menunjukan instrumen yang sudah dipercaya dan dapat menghasilkan data yang dipercaya pula. Pengujian reliabilitas dilakukan dengan cronbach alpha yaitu untuk menguji kelayakan terhadap konsistensi seluruh skala yang digunakan. Suatu instrumen dikatakan reliabel dan dapat digunakan dalam penelitian apabila memiliki croncbach alpha lebih dari atau $>0,6$ (Ghozali. 2011).

Hasil uji realibilitas menunjukkan koefisien cronbach's alpha instrumen (item pernyataan) penelitian dari variabel Keterampilan Manjerial (X1), Kepemimpinan Kepala Sekolah (X2) dan Kepuasan Kerja Guru (Y) pada SMP Swasta se-Kota Pekanbaru menunjukan cronbach's alpha masing-masing koefisien memiliki nilai cronbach's alpha >0,6 sehingga dapat disimpulkan bahwa semua variabel dalam penelitian ini adalah realibel, sehingga data dapat digunakan untuk di analisa selanjutnya.

\section{Hasil Uji Regresi Linear Berganda}

Setelah dilakukan uji asumsi klasik maka dilanjutkan dengan analisis linear berganda. Secara ringkas Hasil Analisis Regresi Linear Berganda ditampilkan oleh Tabel berikut. 
Tabel Hasil Analisis Regresi Linear Berganda

\begin{tabular}{|c|c|c|c|c|c|c|}
\hline \multirow{2}{*}{\multicolumn{2}{|c|}{ Model }} & \multirow{2}{*}{\multicolumn{2}{|c|}{$\begin{array}{l}\text { Unstandardized } \\
\text { Coefficients }\end{array}$}} & \multirow{2}{*}{$\begin{array}{l}\text { Standardized } \\
\text { Coefficients } \\
\text { Beta } \\
\end{array}$} & \multirow[t]{2}{*}{$\mathbf{t}$} & \multirow[t]{2}{*}{ Sig. } \\
\hline & & & & & & \\
\hline \multirow{3}{*}{1} & (Constant) & 1529 & 317 & & 4817 & 0 \\
\hline & Keterampilan manajerial & .232 & .096 & .241 & 2.422 & .017 \\
\hline & $\begin{array}{l}\text { Kepemimpinan kepala } \\
\text { sekolah }\end{array}$ & .342 & .082 & .415 & 4.169 & .000 \\
\hline
\end{tabular}

Tabel 21 di atas menjelaskan variabel bebas keterampilan manajerial (X1) mempunyai nilai $p$ value sebesar 0.017 berarti berpengaruh secara signifikan terhadap kepuasan kerja guru $(\mathrm{P}<0.05)$, variabel bebas kepemimpinan kepala sekolah mempunyai nilai $p$ value sebesar 0.000 berarti berpengaruh secara signifikan terhadap kepuasan kerja guru $(\mathrm{P}<0.05)$, jadi kedua variabel bebas (keterampilan manajerial dan kepemimpinan kepala sekolah) berpengaruh secara signifikan terhadap kepuasan kerja guru. Selanjutnya berdasarkan tabel 4 di atas diperoleh persamaan regresi linier sebagai berikut:

$$
\mathrm{Y}=1.529+0.232 \mathrm{X} 1+0.342 \mathrm{X} 2
$$

Berdasarkan pada persamaan regresi linier berganda tersebut dapat diinterpretasikan sebagai berikut:

1. Konstanta $(\alpha)$ sebesar 1.529 yang berarti apabila tidak ada perubahan variabel independen (ketarampilan manajerial dan kemampuan kepemimpinan kepala sekolah) maka kepuasan kerja guru akan meningkat sebar 1.529 .

2. b1 bertanda positif, artinya variabel keterampilan manajerial berpengaruh positif terhadap kepuasan kerja guru sebesar 0.232 atau sebesar $23.2 \%$ Maksudnya adalah setiap keterampilan manajerial naik satu point maka kepuasan kerja guru naik sebesar $23.2 \%$ maka kepuasan kerja guru meningkat satu point.
3. b2 bertanda positif, artinya variabel bebas kemampuan kepemimpinan kepala sekolah berpengaruh positif terhadap kepuasan kerja guru sebesar 0.342 atau sebesar $34.2 \%$. Maksudnya adalah setiap kemampuan kepemimpinan kepala sekolah naik satu poin maka kepuasan kerja guru naik sebesar $34.2 \%$.

Kemampuan kepemimpinan kepala sekolah mempunyai pengaruh yang dominan, karena nilai koefisien regresi paling besar (0.342) atau sebesar $34.2 \%$.

Kepemimpinan kepala sekolah yang efektif sangatlah dipengaruhi oleh kemampuan kepala sekolah itu sendiri. Sebagai pemimpin, kepala sekolah tetap eksis pada situasi apa pun. Ada atau tidak adanya krisis di sekolah, kepala sekolah mampu menghantarkan sekolah mencapai tujuan yang telah ditetapkan. Disini diperlukan keluwesan dan fleksibelitas kepala sekolah yang ditopang oleh energi warga sekolah. Kepala sekolah luwes, bersikap terbuka terhadap gagasan-gagasan baru mengenai cara penanganan krisis, serta mengajak warga sekolah untuk terlibat secara aktif mengatasi krisis.

\section{Uji Ketepatan Model (Uji F)}

Uji ketepatan model (uji F) disajikan oleh Tabel berikut. 
Tabel. Uji F

\begin{tabular}{lllllll}
\hline Model & $\begin{array}{l}\text { Sum } \\
\text { Squares }\end{array}$ & of & $\begin{array}{l}\text { Mean } \\
\text { Square }\end{array}$ & F & Sig. \\
\hline \multirow{2}{*}{1} & Regression & 8.297 & 2 & 4.149 & 22.113 & $.000^{\mathrm{b}}$ \\
\cline { 2 - 7 } & Residual & 16.885 & 90 & .188 & & \\
\cline { 2 - 7 } & Total & 25.183 & 92 & & & \\
\hline
\end{tabular}

a. Dependent Variable: Kepuasan kerja guru

b. Predictors: (Constant), Kepemimpinan kepala sekolah, Keterampilan manajerial

Berdasarkan Tabel 5 di atas dapat dilihat bahwa dari uji simultan menghasilkan nilai $\mathrm{F}_{\text {hitung }}$ sebesar 22.113 dengan tingkat signifikansi 0.000 . Nilai $\mathrm{F}_{\text {tabel }}$ untuk model regresi di atas adalah 2.32 (degree of freedom $(\mathrm{df})=\mathrm{n}-\mathrm{k})$, sehingga nilai $\mathrm{F}_{\text {hitung }} 22.113>$ nilai $\mathrm{F}_{\text {tabel }} 2.32$; dengan sig $0.000<0.05$, hasil ini menunjukkan bahwa variabel independen yang terdiri dari kemampuan manajerial dan kepemimpinan kepala sekolah secara bersama-sama mempunyai pengaruh yang positif signifikan terhadap variabel dependent yaitu kepuasan kerja guru di SMP Swasta Kota Pekanbaru.

\section{Uji Koefisien Determinasi $\left(\mathbf{R}^{\mathbf{2}}\right)$}

Koefisien Determinasi digunakan untuk mengetahui kemampuan variabel independen dalam menjelaskan variabel dependen, dengan hasil sebagai berikut .

Tabel. Hasil Koefisiensi Determinasi

\begin{tabular}{lllll}
\hline Model & R & R Square & Adjusted R Square & $\begin{array}{l}\text { Std. Error of the } \\
\text { Estimate }\end{array}$ \\
\hline 1 & $.574^{\mathrm{a}}$ & .329 & .315 & .433 \\
\hline a. Predictors: (Constant), Kepemimpinan kepala sekolah, Keterampilan manajerial \\
\hline
\end{tabular}

Berdasarkan Tabel 6, hasil perhitungan perkiraan regresi diperoleh nilai koefisien determinasi adalah 0.329 artinya variasi variabel terikat mampu dijelaskan oleh variasi himpunan variabel bebas dalam model tersebut sebesar $32.9 \%$. Sisanya $67.1 \%$ dijelaskan oleh variabel di luar model yang diteliti, misalnya: gaya kepemimpinan, kompensasi, iklim organisasi, komitmen professional, komitment organisasi, budaya organisasi sekolah, dan lain-lain. Gibson, Ivancevich dan Donnely dalam Werang (2012) mengatakan apabila kepala sekolah menjalankan tugas kepemimpinan manajerialnya secara efektif, para guru akan merasa terdorong memberikan kontribusi nyata dalam usaha merealisasikan visi dan misi sekolah.

\section{Kesimpulan}

Kesimpulan dari penelitian ini sebagai berikut:

1) keterampilan manajerial berpengaruh positif terhadap kepuasan kerja guru sebesar 0.232 atau sebesar $23.2 \%$;

2) kemampuan kepemimpinan kepala sekolah berpengaruh positif terhadap kepuasan kerja guru sebesar 0.342 atau sebesar 34.2\%;

3) kemampuan manajerial dan kepemimpinan kepala sekolah secara bersama-sama mempunyai pengaruh yang positif signifikan terhadap variabel dependent yaitu kepuasan kerja guru di SMP Swasta Kota Pekanbaru.

\section{DAFTAR PUSTAKA}


Dinas Pendidikan Kota Pekanbaru. 2016.

Rekap Kepegawaian Guru dan Kepala Sekolah SMP Swasta Kota Pekanbaru. Dinas Pendidikan. Pekanbaru

Robbins, S.P., and Judge, T.A. 2008. Perilaku Organisasi. Edisi Kedua belas. Salemba Empat. Jakarta

Robbins, Stephen P. 2010. Perilaku Organisasi Konsep Kontroversi Aplikasi. Edisi 8, Jilid 1, Terjemahan. Prehalindo. Jakarta Wahyuni, Dewi dan Urip. 2011. Pengaruh Komitmen Organisasional Dan Motivasi Terhadap Kinerja Guru STS Di Surabaya Jurnal Mitra Ekonomi dan Manajemen Bisnis, Fakultas Ekonomi, STIE Fatahillah Surabaya. 2(1):60-78

Werang, B, R. 2012. Hubungan Keterampilan Manajerial Kepala Sekolah, Iklim Sekolah, dan Moral Kerja Guru dengan Kinerja Guru SMA Negeri di Kota Merauke. Jurnal Aplikasi Manajemen. 10 (3): 595-605. 
